\title{
Adequate Advance Provided by a Familiar Fluid Dynamic Balance Principle to Tools and Techniques for Water Quality Interpretation: Experienced in Yaoundé (Cameroun) 2nd Supply Dam
}

\author{
Kom Olivia Estelle, Mbane Biouele César* \\ Laboratory of Earth's Atmosphere Physics, Department of Physics, University of Yaoundé I, \\ Yaoundé, Cameroun \\ Email: $\underline{\text { cesar.mbane@yahoo.fr }}$
}

Received 2 January 2015; accepted 24 January 2015; published 27 January 2015

Copyright @ 2015 by authors and Scientific Research Publishing Inc.

This work is licensed under the Creative Commons Attribution International License (CC BY). http://creativecommons.org/licenses/by/4.0/

\section{(c) (i) 0pen Access}

\begin{abstract}
In a fluid (liquid or gas) at rest, the isobars are horizontal surface. This fluid dynamic balance theorem provides adequate advance to tools and techniques for Water Quality Interpretation. We deal in this paper, with an effective way of exploiting the familiar communicating containers' principle. That formally consists on providing water samples from desired depths of rivers, oceans, retention dams, etc. The prevailing limiting factor to achieve this feat is the length of our sampling pipes named Mbane Bathymetric Tube (MBT) designed for this purpose when rivers or retention dams are very deep. Providing drinking water to urban growing populations is a challenge that no government can escape. Therefore, improving the tools and techniques for water quality interpretation is an adequate advance for drinking water managerial techniques because this allows the recovery of contaminated water which abounds on the earth by acquiring appropriate wastewater treatment stations. The aim of the manuscript is to provide a brief theoretical description of our designed sampling equipment to allow everyone who is going to use it to solve in advance problems brought by Archimedes' pressure force when experiencing the sampling pipes. Archimedes' pressure force acts mainly when moving the sampling pipes to water lower levels and then opening its protective cover which allows the communication with the supply dam.
\end{abstract}

\section{Keywords}

Communicating Containers' Principle, Water Samples from Desired Depths of Rivers, Mbane

\footnotetext{
${ }^{*}$ Corresponding author.
}

How to cite this paper: Estelle, K.O. and César, M.B. (2015) Adequate Advance Provided by a Familiar Fluid Dynamic Balance Principle to Tools and Techniques for Water Quality Interpretation: Experienced in Yaoundé (Cameroun) $2^{\text {nd }}$ Supply Dam. Open Journal of Marine Science, 5, 158-168. http://dx.doi.org/10.4236/ojms.2015.51013 


\section{Bathymetric Tube (MBT), Tools for Water Quality Interpretation}

\section{Introduction}

The Yaoundé $2^{\text {nd }}$ supply dam water, located in Nkolbisson-Minkoameyos village is exposed to demographic pressure. Indeed, the lake is contaminated by all kinds of domestic waste directly disposed on the rivers upstream from supply dam water or brought by runoff and floods in the rainy seasons. The main interest of Minkoameyos' Lake is that it is the largest and least exposed hitherto of well-known public Lakes that hosts Yaoundé city (e.g., Ngoa-Ekelle, Minkoameyos, Atemengue, Melen, Obili, Olezoa, Oyomabang, Emana, and Municipal Lake). Abandoned for years, this lake in the past supply water to Yaoundé populations and it is now experiencing a resurgence of interest [1]-[5] provided by the rehabilitation project launched since August 2011 by CAMWATER Company. To reassure consumers of water supplied by Minkoameyos Lake, it is important to organize more often, campaigns on physicochemical and bacteriological analyzes of water samples from surface to desired depths of the lake. Confidence necessary to safeguard the mutual interests of CDE-CAMWATER Companies (companies in charge with drinking water management) and consumers can thus be established and strengthened at the same time. Everyone knows that, in a fluid (liquid or gas) at rest, the isobars are horizontal surface. This fluid dynamic balance theorem provides a familiar communicating containers' principle which statement is: surfaces of both communicating containers' liquid at rest in contact with the atmosphere also at rest are in the same horizontal plane. Those above and very useful hydrodynamics theorem and principle have many industrial applications such as vertical alignment of the walls in houses' building, horizontal alignment of bridge or providing drinking water to each house in town. We deal in this paper, with an adequate and effective way of exploiting the communicating containers' principle. Our work formally consists on providing water samples from desired depths of Nkolbisson Lake. A designed tube for this purpose named Mbane Bathymetric Tube (MBT) has been conceived and built in order to improve the tools and techniques for water quality interpretation. Our experience in Nkolbisson Lake is an adequate advance for drinking water managerial techniques because it allows an appropriate peer treatment of contaminated water which quality interpretation is irrefutable. Finding out more about the causes of the disease must be a prerequisite before looking for appropriate treatment of that disease (in our case: Finding out more about wastewater physicochemical and bacteriological interpretation is a great challenge before acquiring adequate treatment station).

\section{Communicating Containers' Principle}

Everyone must learn a little more about communicating container's principle which is valid only when both liquid and atmosphere are at rest.

\subsection{Forces of Significance in Fluid Motion}

\section{a. Gravity Force}

Since physic is dealing with the masses in the vicinity of the earth, we shall consider the mass of the earth $\left(M_{e}\right)$ and any other mass $(m)$. For the time being we shall neglect the fact that the earth is rotating. Moreover, we shall assume that the earth is a homogeneous sphere with its center of mass at its geometrical center, so that we can chose the earth's center as the origin of a coordinate system. The assumption of homogeneity is a good assumption for most fluid dynamic requirements. Suppose a point $P$ is located at distance $O P=r$ from the center of the spherical earth, as shown in Figure 1. The location of $P$ with respect to the earth's center is given by the position vector $\boldsymbol{r}=r \nabla \cdot r$. A mass $m$ located at $P$ is subject to the force of gravitation $F_{g}$ of magnitude $F_{g}=G \cdot m \cdot M_{e} / r^{2}$. This force (Figure 1) accelerates the mass toward the earth, and the acceleration vector, or the force of gravitation is

$$
\boldsymbol{F}_{g}=-G \frac{m M_{e}}{r^{2}} \nabla \cdot r
$$

Since the acceleration is directed opposite to the unit vector $\nabla \cdot r$, we usually deal with unit mass, so that $m=$ 1 and we write the force of gravitation for unit mass in the form

$$
\boldsymbol{g}_{a}=-\frac{G_{e}}{r^{2}} \nabla \cdot r
$$




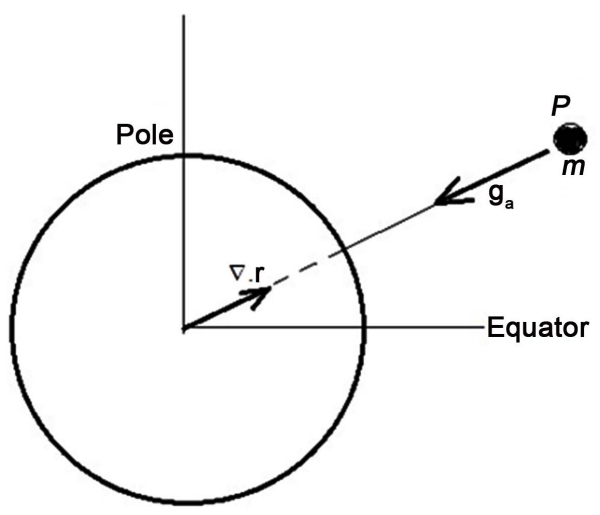

Figure 1. The mass $(m)$ located at $P$ is subject to the force of gravitation, directed as shown.

where $G_{e}=G \cdot M_{e}$ is called the earth's gravitational constant. Numerical values of the pertinent constant are:

$$
\begin{aligned}
& G=6.673 \times 10^{-11} \mathrm{~N} \cdot \mathrm{m}^{2} \cdot \mathrm{kg}^{-2} \\
& M_{e}=5.983 \times 10^{24} \mathrm{~kg} \\
& G_{e}=3.992 \times 10^{14} \mathrm{~N} \cdot \mathrm{m}^{2} \cdot \mathrm{kg}^{-1}
\end{aligned}
$$

\section{b. Frictional Forces/Pressure Forces}

Frictional forces (Figure 2 and Figure 3) act on the surface of a fluid volume. They are stresses. There are normal stresses and tangential stresses. If the fluid is completely at rest, all tangential stresses must vanish, and only normal stresses can remain (this fact distinguishes fluids from solids, because solids can remain at rest even when they are subject to tangential stresses). Thus, in a state of rest or equilibrium, the normal stresses must be defined in such a way they reduce to the hydrostatic pressure when the fluid is at rest.

The magnitude of viscous frictional force, $F$, is

$$
F=\mu \frac{A}{L} U_{o}
$$

where $(\mu)$ is the viscosity of the fluid and $(A)$ the acting area.

Resulting component of frictional force along the $\mathrm{x}$-axis is obtained by (4),

$$
F_{v x}=\left(\tau_{z x}+\frac{\partial \tau_{z x}}{\partial z} \frac{\delta z}{2}\right) \delta x \delta y-\left(\tau_{z x}-\frac{\partial \tau_{z x}}{\partial z} \frac{\delta z}{2}\right) \delta x \delta y
$$

Then

$$
F_{v x}=\frac{\partial \tau_{z x}}{\partial z} \delta x \delta y \delta z
$$

Whether hydrostatic or not, the pressure is defined as force per unit area. Accordingly, the pressure force $P$ is equal to pressure time's area. We shall treat the pressure as hydrostatic and as a normal stress (Figure 4).

Component of pressure force along the $\mathrm{x}$-axis results from following relations:

$$
P_{A}=P_{M}+\frac{\partial P}{\partial x} \frac{\delta x}{2}+\varepsilon(x)
$$

$\varepsilon(x)$ is negligible with respect to $P_{M}+\frac{\partial P}{\partial x} \frac{\delta x}{2}$,

The pressure force $F_{A X}$, acting on Face $A$ of rectangular parcel is

$$
F_{A X}=-\left(P_{M}+\frac{\partial P}{\partial x} \frac{\delta x}{2}\right) \delta y \delta z
$$

On Face $B$ : 


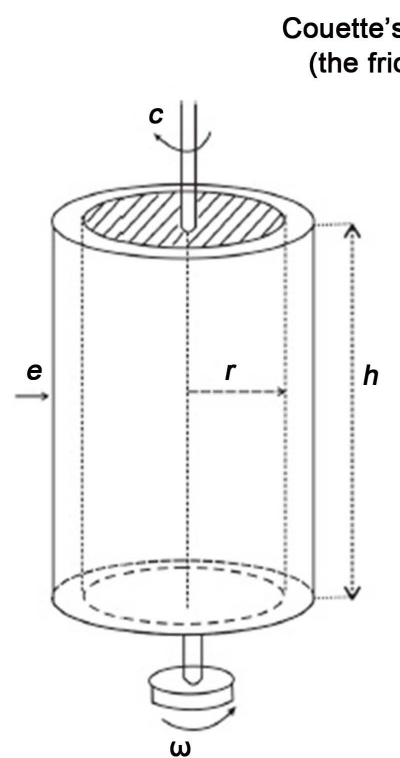

Couette's proofs of frictional forces existences

(the frictional forces are retarding forces)

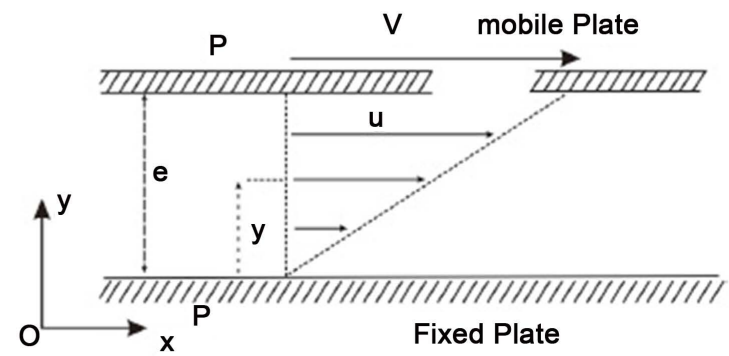

Frictional forces act on fluid between plates and triggered a velocity field $U(y)$.

Figure 2. Couette’s proofs of frictional forces existences (the frictional forces are retarding forces).

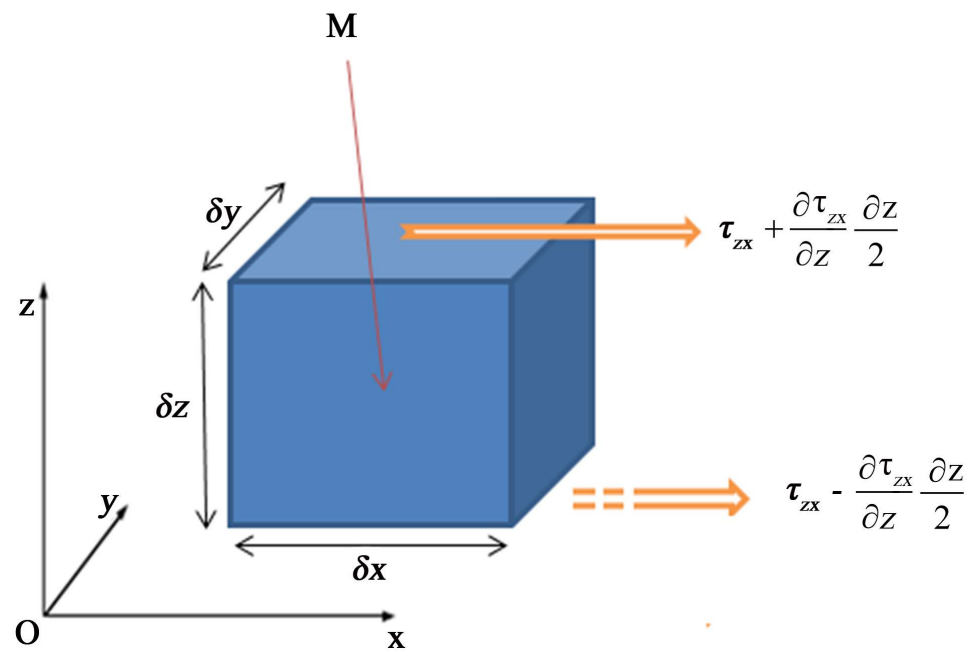

Figure 3. Component of frictional force along the $\mathrm{x}$-axis.

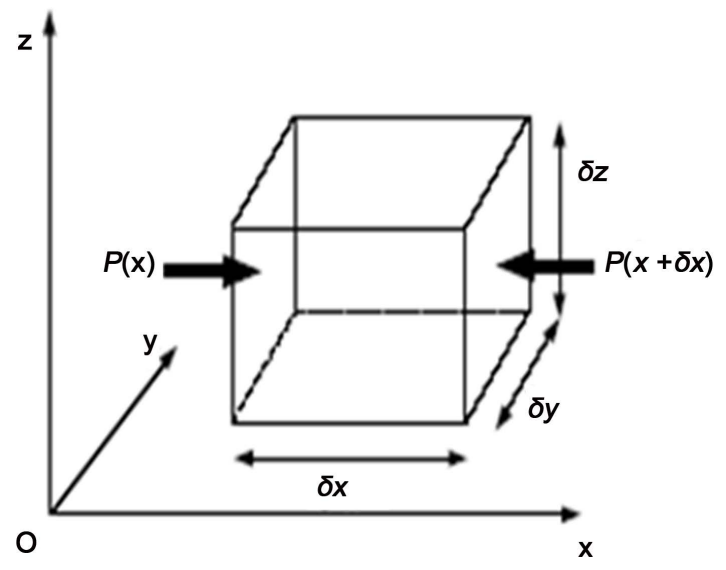

Figure 4. Component of pressure force along the $\mathrm{x}$-axis. 


$$
F_{B X}=+\left(P_{M}-\frac{\partial P}{\partial x} \frac{\delta x}{2}\right) \delta y \delta z
$$

Therefore the component of pressure force along rectangular coordinates axis

$$
\begin{gathered}
F_{X}=F_{A X}+F_{B X}=-\frac{\partial P}{\partial x} \delta x \delta y \delta z \\
F_{Y}=-\frac{\partial P}{\partial y} \delta x \delta y \delta z \\
F_{Z}=-\frac{\partial P}{\partial z} \delta x \delta y \delta z
\end{gathered}
$$

\subsection{Hydrostatic Equations}

In a state of rest or equilibrium, the normal stresses must be defined in such a way they reduce to the hydrostatic pressure when the fluid is at rest. For a unit mass of fluid, Newton $3^{\text {rd }}$ law provides a relationship between pressure forces $\boldsymbol{F}_{P}$ and gravity force $\boldsymbol{F}_{g}$

$$
\frac{\mathrm{d}}{\mathrm{d} t} \boldsymbol{V}=\mathbf{0}=\boldsymbol{F}_{P}+\boldsymbol{F}_{g}
$$

The projections of (12) along rectangular coordinates axis give

$$
\begin{aligned}
& \frac{\partial P}{\partial x}=0 \\
& \frac{\partial P}{\partial y}=0
\end{aligned}
$$

Hence the familiar fluid at rest state equation

$$
\mathrm{d} P=-\rho \cdot g \cdot \mathrm{d} z
$$

\subsection{Communicating Containers Principle}

According to Equation (15), isobars (whose equation is $\mathrm{d} P=0$ ) in a fluid at rest are horizontal surfaces (due to the fact that horizontal surface equation is $\mathrm{d} z=0$ ). Now one can compare liquid-at-rest-surfaces of communicating containers with atmosphere-at-rest-lower boundary isobar. Both surfaces are in the same horizontal plane (the Atmosphere at rest lower boundary isobar in this case). Hence the communicating containers principle statement: surfaces of both communicating containers' liquid in contact with the atmosphere at rest are in the same horizontal plane (Figure 5).

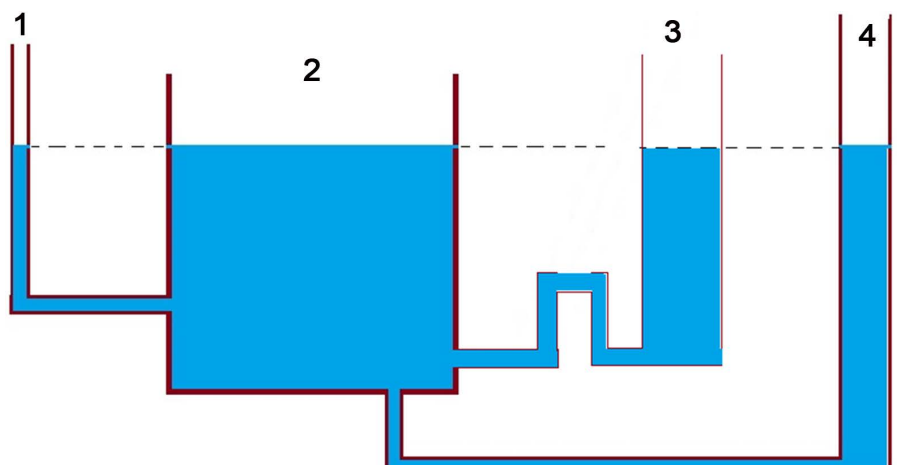

Figure 5. Both summits of the communicating containers' liquid at rest are at the same horizontal surface. 


\subsection{Mbane Bathymetric Tube (MBT)}

The purpose of our work is to improve tools and technique for water quality interpretation throughout campaigns on physicochemical and bacteriological analyzes of water samples from surface to desired depths of the wastewaters lake. A designed tube for this purpose named Mbane Bathymetric Tube (MBT) has been conceived and built by C. Mbané Biouélé according to communicating containers principle (Figure 6).

Once the MBT is dropped at the desired depth $\mathrm{H}$, the little door $\mathrm{C} 1$ allows communication with the wastewaters dam and liquid at the desired depth $\mathrm{H}$ will pull into the empty tube together with the water sample collector pan till the summit of the liquid inside the tube reach the surface of water around the MBT. The MBT must be removing vertically from water and the water-sample collecting (throughout the little door C2) thereafter. The Mbane Bathymetric Tube will provide adequate advance to tools and techniques for studies on the REEs (rare earth elements) [6]-[21]. Indeed, assembling many tubes of reasonable length one after the other (as do engineers on oil rigs), water samples will be taken at greater depths up to $100 \mathrm{~m}$ or more.

\section{Experience in Yaoundé-Nkolbisson Wastewaters Dam}

The Yaoundé $2^{\text {nd }}$ dam water retention or lake, located in Yaoundé neighborhoods (Nkolbisson-Minkoameyos village in this case (Figure 7)) is exposed to demographic pressure. For this reason, this lake is contaminated by all kinds of domestic waste directly disposed on the rivers upstream from lake or brought by runoff and floods in the rainy seasons. The main interest of Minkoameyos' Lake is that it is the largest and least exposed hitherto of well-known public lakes that hosts Yaoundé city (e.g., Ngoa-Ekelle, Minkoameyos, Atemengue, Melen, Obili, Olezoa, Oyomabang, Emana, and Municipal Lake). Abandoned for years, this lake in the past supply water to Yaoundé populations and it is now experiencing a resurgence of interest provided by the rehabilitation project launched since August 2011 by CAMWATER Company. To reassure consumers of water supplied by Minkoameyos Lake, it is important to organize more often, campaigns on physicochemical and bacteriological analyzes of water samples from surface to desired depths of the lake. Indeed, finding out more about wastewaters bacterial or chemical pollution before equipping (or acquiring) water treatment station is now possible with our MBT for unlimited desired depths.

Our campaigns (Figure 8) on physicochemical and bacteriological analyzes of water samples coming from surface to desired depths of the Yaoundé $2^{\text {nd }}$ supply dam was performed on July 03, 2014. Our difficulty was the lack of financial support mainly for physicochemical and bacteriological analyzes fees. Indeed, we were not able

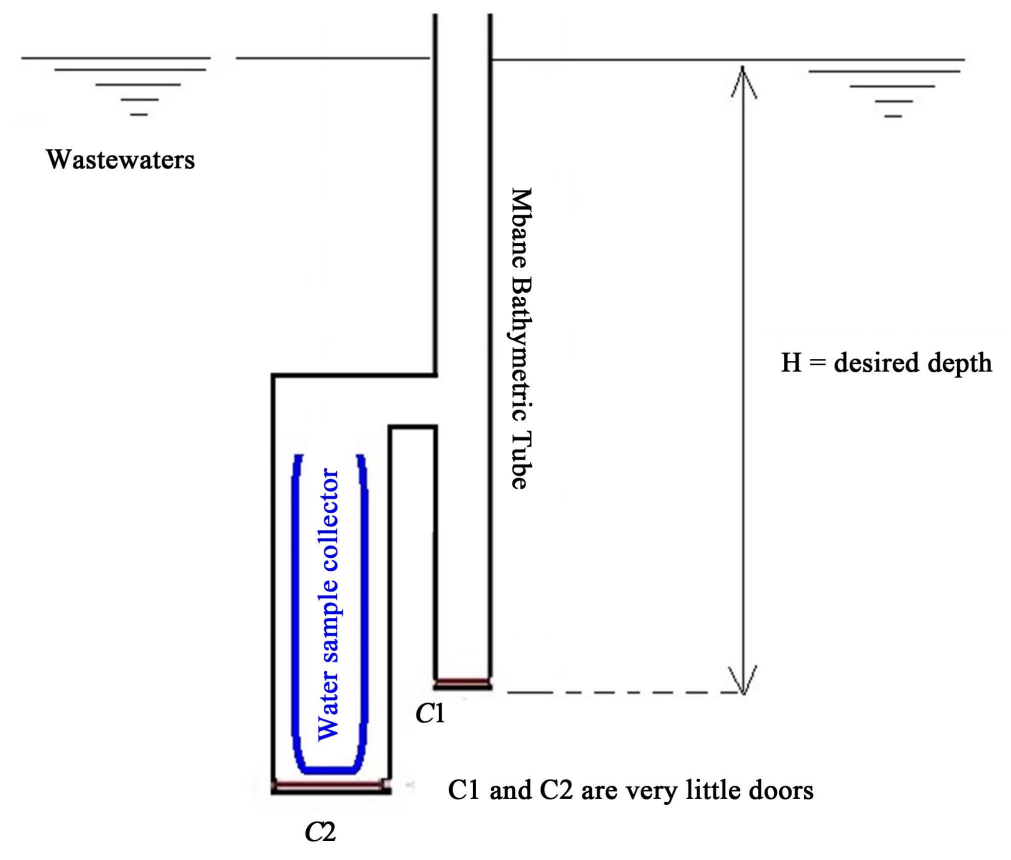

Figure 6. Schematic representation of Mbane Bathymetric Tube. 


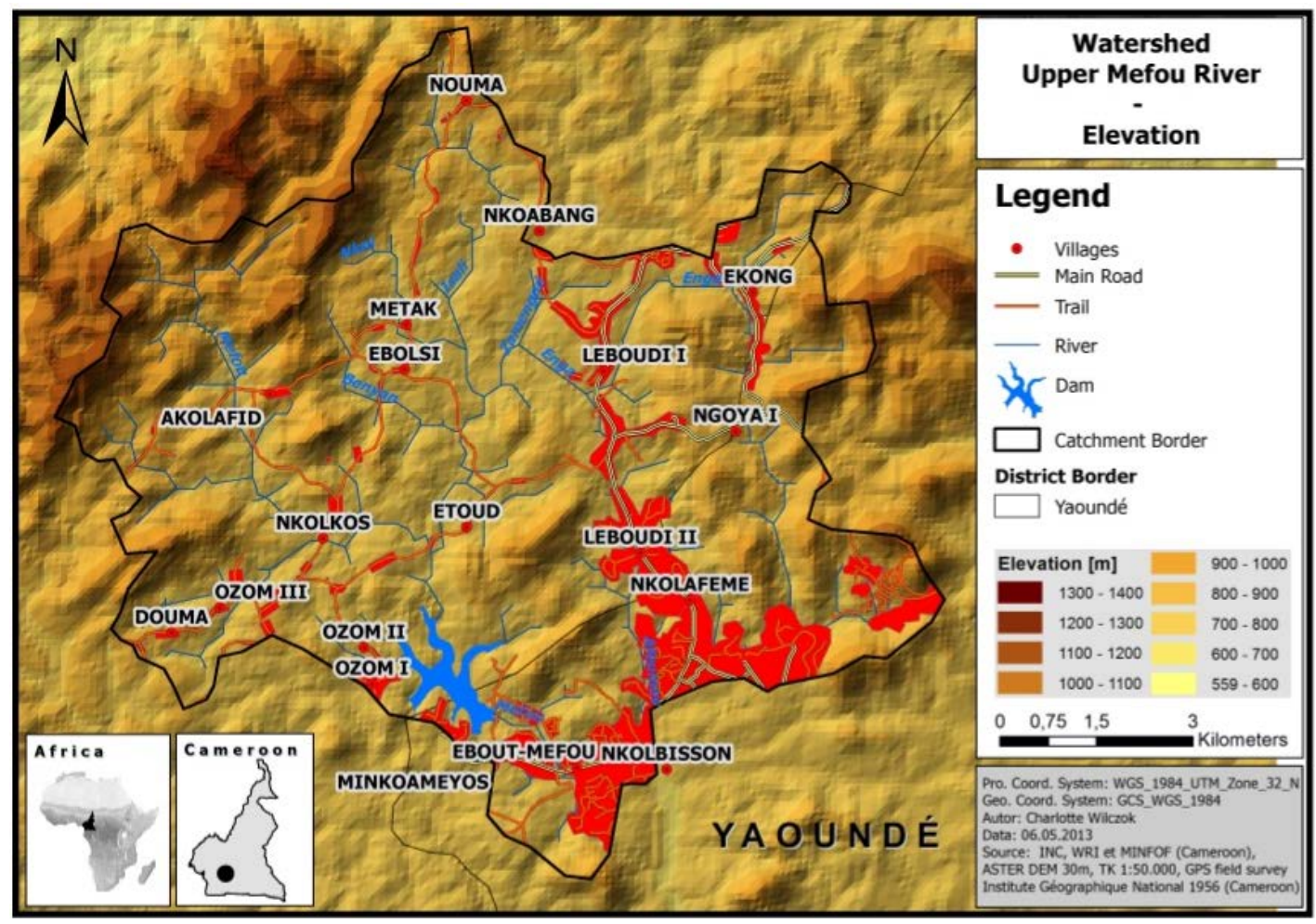

Figure 7. Administrative and geographical presentation of Yaoundé-Nkolbisson supply dam.
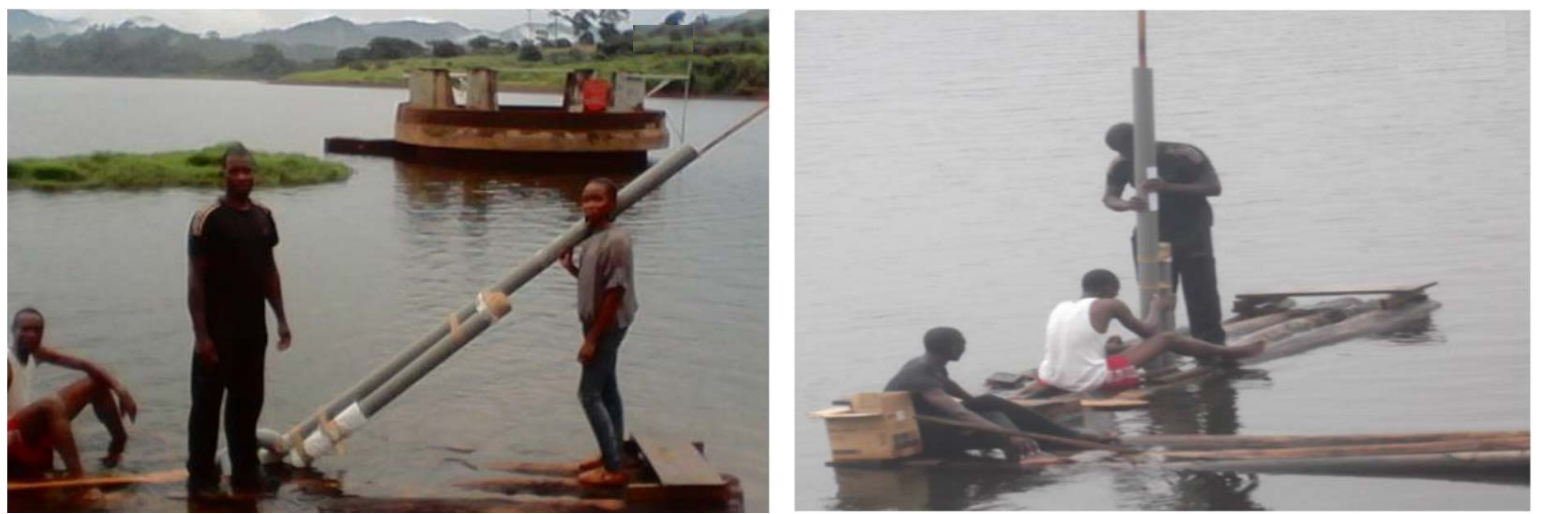

Figure 8. Photographs on the MBT experimental and using contexts.

to analyze more than 09 water samples. That is why only 03 database pointes (DBP) has been choice as shown on Figure 9.

\section{Brief Results and Discussion}

Table 1 contains analysis results of various wastewater samples coming from different desired depths (0 meter, 1 meter, 2 meters) of the Yaoundé $2^{\text {nd }}$ supply dam. The results in Table 1 show that levies on the water surface provide false or incomplete information on the quality of deep layers of the dam. Matters known as suspension one are also find in 1 meter deep as well as 2 meters. Moreover, nothing prevents suspension matters to exist inside 6 - 7 or 8 meters layers. One should talk about immersion matters: which perfectly corresponds to Thermodynamics or Physics perception of the concept of density of a body. Histograms on the suspended matters' concentration and $\mathrm{pH}$ values of wastewater at various desired depths are presented in Figures 10(a)-(d) and Figure 11. 


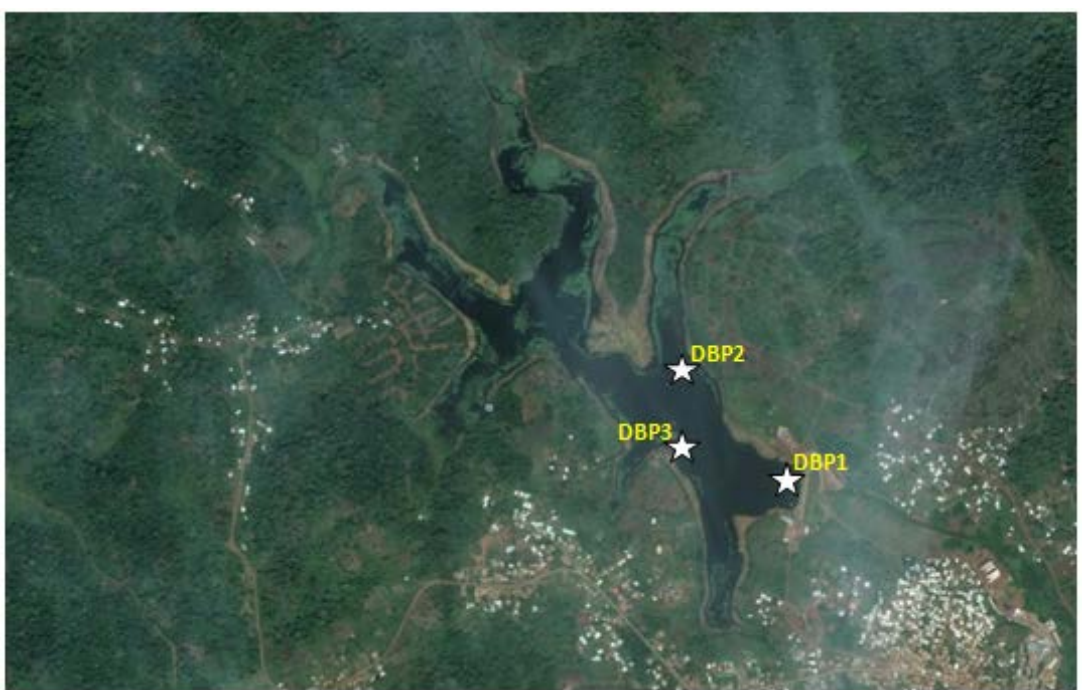

Figure 9. The database points’ localization DBP = Data-Base-Point.

Table 1. Bacteriological and physicochemical situation of Yaoundé-Nkolbisson $2^{\text {nd }}$ supply dam (July 03, 2014).

\begin{tabular}{|c|c|c|c|c|}
\hline $\begin{array}{l}\text { Physicochemical or } \\
\text { bacteriological parameters }\end{array}$ & $\begin{array}{l}\text { Physicochemical or bacteriological parameters with } \\
\text { regard to desired depth } \mathrm{j} \text { (meter) })_{\mathrm{j}=0,1,2}\end{array}$ & $\mathrm{P}_{1}=\mathrm{DBP}_{1}$ & $\mathrm{P}_{2}=\mathrm{DBP}_{2}$ & $\mathrm{P}_{3}=\mathrm{DBP}_{3}$ \\
\hline \multirow{3}{*}{$\mathrm{pH}$} & $\mathrm{pH}_{0 \mathrm{~m}}$ & 7.37 & 7.20 & 7.11 \\
\hline & $\mathrm{pH}_{1 \mathrm{~m}}$ & 7.48 & 7.21 & 7.15 \\
\hline & $\mathrm{pH}_{2 \mathrm{~m}}$ & 7.30 & 7.19 & 7.05 \\
\hline \multirow{3}{*}{ IMM (mg/l) } & $\operatorname{IMM}(\mathrm{mg} / \mathrm{l})_{0 \mathrm{~m}}$ & 9 & 4 & 2 \\
\hline & $\operatorname{IMM}(\mathrm{mg} / \mathrm{l})_{1 \mathrm{~m}}$ & 3 & 3 & 4 \\
\hline & $\mathrm{IMM}(\mathrm{mg} / \mathrm{l})_{2 \mathrm{~m}}$ & 21 & 4 & 4 \\
\hline \multirow{3}{*}{ TDS (mg/l) } & TDS $(\mathrm{mg} / \mathrm{l})_{0 \mathrm{~m}}$ & 10.87 & 10.98 & 11.33 \\
\hline & TDS $(\mathrm{mg} / \mathrm{l})_{1 \mathrm{~m}}$ & 10.68 & 10.86 & 12.36 \\
\hline & TDS $(\mathrm{mg} / \mathrm{l})_{2 \mathrm{~m}}$ & 10.98 & 10.74 & 11.33 \\
\hline \multirow{3}{*}{ FC (FCU/100ml) } & $\mathrm{FC}(\mathrm{FCU} / 100 \mathrm{ml})_{0 \mathrm{~m}}$ & 57 & 12 & 11 \\
\hline & $\mathrm{FC}(\mathrm{FCU} / 100 \mathrm{ml})_{1 \mathrm{~m}}$ & 49 & 19 & 8 \\
\hline & $\mathrm{FC}(\mathrm{FCU} / 100 \mathrm{ml})_{2 \mathrm{~m}}$ & 17 & 16 & 37 \\
\hline \multirow{3}{*}{ Cnd $(\mu \mathrm{S} / \mathrm{Cm})$} & Cnd $(\mathrm{mS} / \mathrm{Cm})_{0 \mathrm{~m}}$ & 25.4 & 23 & 22.7 \\
\hline & Cnd $(\mathrm{mS} / \mathrm{Cm})_{1 \mathrm{~m}}$ & 23 & 23 & 26.2 \\
\hline & Cnd $(\mathrm{mS} / \mathrm{Cm})_{2 \mathrm{~m}}$ & 23.6 & 25.3 & 24.4 \\
\hline \multirow{3}{*}{ Salt (\%) } & Salt $(\%)_{0 \mathrm{~m}}$ & 0.01 & 0.1 & 0.01 \\
\hline & Salt $(\%)_{1 \mathrm{~m}}$ & 0.01 & 0.1 & 0.01 \\
\hline & Salt $(\%)_{2 \mathrm{~m}}$ & 0.01 & 0.1 & 0.01 \\
\hline
\end{tabular}

Immerging Matters = IMM; Total Dissolved Solid = TDS; Fecal Coliforms = FC; Electrical Conductivity $=\mathrm{C}_{\text {nd }}$. 


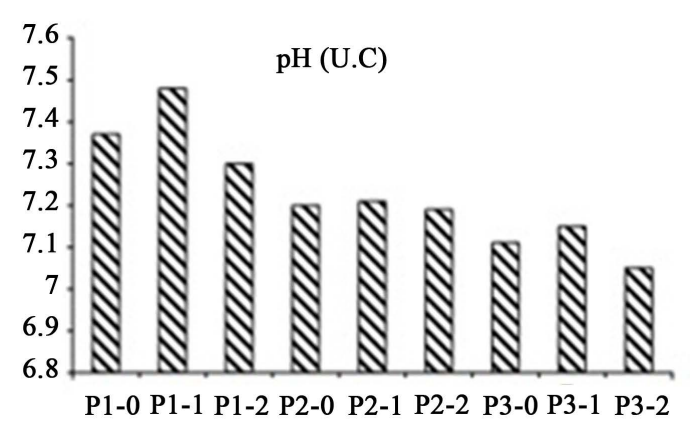

(a)

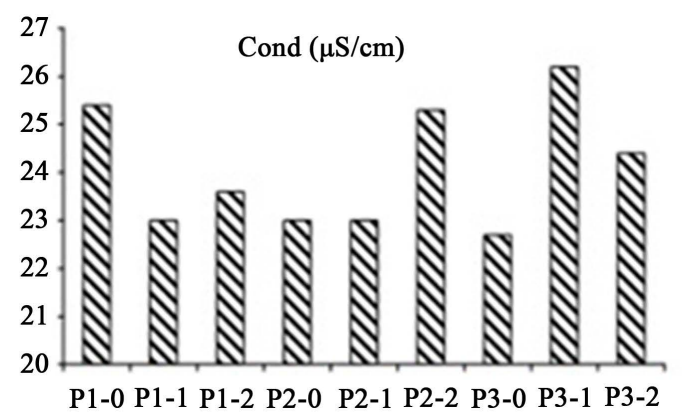

(c)

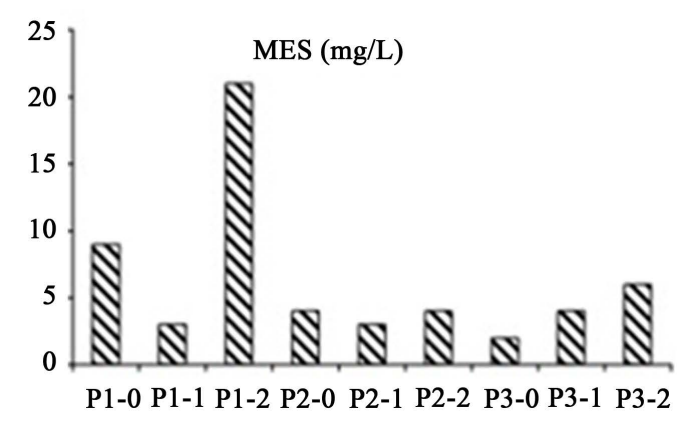

(b)

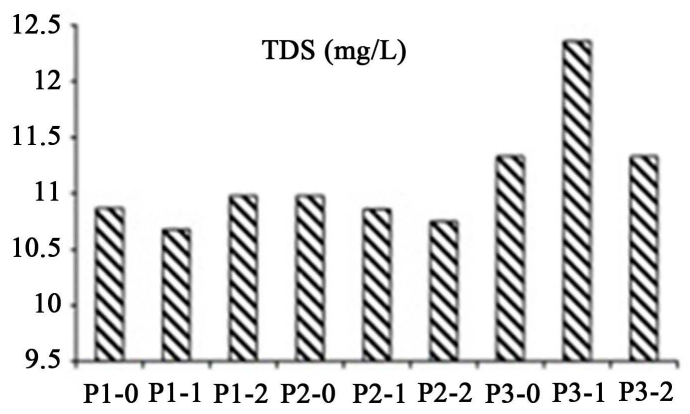

(d)

Figure 10. (a)-(d) Physicochemical and bacteriological constituents’ histograms.

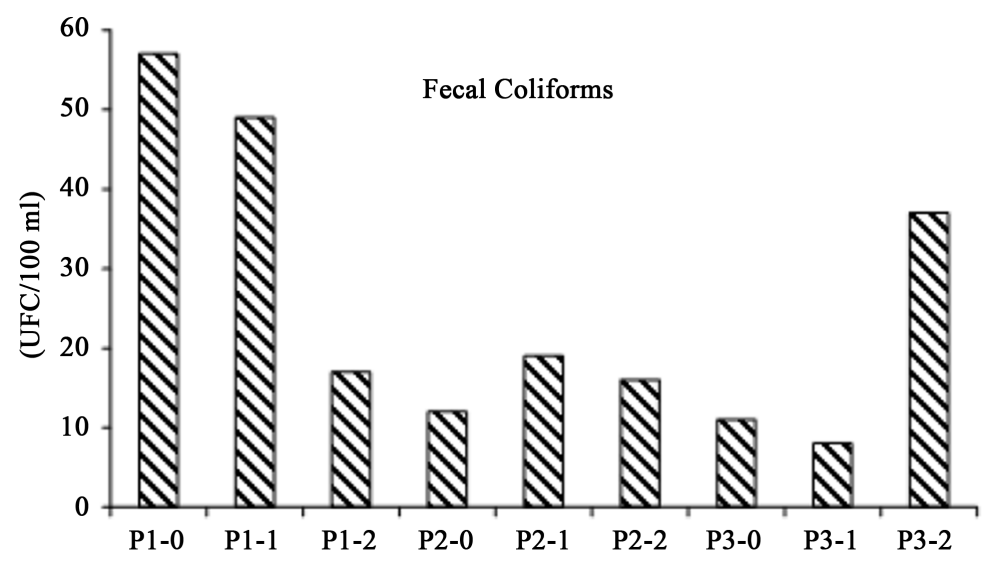

Figure 11. Fecal Coliforms’ histogram.

In a fluid (liquid or gas) at rest, the isobars are horizontal surface. This fluid dynamic balance theorem provides adequate advance to tools and techniques for Water Quality Interpretation. We have deal in this manuscript with an effective way of exploiting the familiar communicating containers' principle. That formally consists on providing water samples from desired depths of rivers, oceans, retention dams, etc. as shown on Table 1 and related histograms (Figure 10) and Figure 11.

\section{Conclusion}

The aim of our study was to provide a new tool to conventional protocols (i.e., Tools and Techniques) developed for the collection of water samples. All protocols known today, did not allow to go down more than 30 centimeters in depth without the risk of contamination of water samples when they are bring to the surface. Due to lack of financial support, the team who did the taking of water samples was forced to move on tree trunks as presented in Figure 8(a) and Figure 8(b). We were able to perform many other samples to ensure a wider coverage 
of the lake. But this would have been useless for the simple reason that the laboratory tests are expensive. The effectiveness of the MBT, however, was demonstrated in this experiment. The MBT-protocol will allow the authorities responsible for the management of drinking water resources in Cameroon, to better equip the Camwater wastewaters treatment stations. More adequate measures campaigns will help to identify potential exogenous (and endogenous) contaminating sources of the dam and to eradicate them. We are considering very carefully the modeling of the physicochemical and biological evolution of the basin pollutants in order to allow (with appropriate applications) the site to be under the satellites surveillance. This approach will allow to remotely controlling the level of contamination of this strategic site.

\section{References}

[1] Braun, J.J., Ndam Ngoupayou, J.R., Viers, J., Dupre, B., Bedimo Bedimo, J.P., et al. (2005) Present Weathering Rates in a Humid Tropical Watershed: Nsimi, South Cameroon. Geochimica et Cosmochimica Acta, 69, 357-387. http://dx.doi.org/10.1016/j.gca.2004.06.022

[2] Tanawa, E., Djeuda Tchapnga, H.B., Ngnikam, E., Temgoua, E. and Siakeu, J. (2000) Habitat and Protection of Water Resources in Suburban Areas in Africa Cities. Building and Environment, 37, 269-275.

http://dx.doi.org/10.1016/S0360-1323(01)00024-5

[3] Viers, J., Dupre, B., Braun, J.J., Deberdt, S., Angeletti, B., et al. (2000) Major and Trace Element Abundances, and Strontium Isotopes in the Nyong Basin Rivers (Cameroon): Constraints on Chemical Weathering Processes and Elements Transport Mechanisms in Humid Tropical Environments. Chemical Geology, 169, 211-241. http://dx.doi.org/10.1016/S0009-2541(00)00298-9

[4] Ostrom and Elinor (2009) A General Framework for Analyzing Sustainability of Social-Ecological Systems. Science, 325, 419-421.

[5] Léopold, E.N., et al. (2008) Metals Pollution in Freshly Deposited Sediments from River Mingoa, Main Tributary to the Municipal Lake of Yaoundé, Cameroon. Geosciences, 12, 337-347. http://dx.doi.org/10.1007/s12303-008-0034-5

[6] Elderfield, H., Upstill-Goddard, R. and Sholkovitz, E.R. (1990) The Rare Earth Elements in Rivers, Estuaries and Coastal Seas and Their Significance to the Composition of Ocean Waters. Geochimica et Cosmochimica Acta, 54, 971-991. http://dx.doi.org/10.1016/0016-7037(90)90432-K

[7] Sholkovitz, E.R. (1992) Chemical Evolution of Rare Earth Elements: Fractionation between Colloidal and Solution Phases of Filtered River Water. Earth and Planetary Science Letter, 114, 77-84. http://dx.doi.org/10.1016/0012-821X(92)90152-L

[8] Rousseau, D., Dupré, D.B., Gaillardet, J. and Allègre, C.J. (1996) Major and Trace Elements of River-Borne Material: The Congo Basin. Geochimica et Cosmochimica Acta, 60, 1301-1321. http://dx.doi.org/10.1016/0016-7037(96)00043-9

[9] Ramesh, R., Ramanathan, A.L., Ramesh, S., Purvaja, R. and Subramanian, V. (2000) Distribution of Rare Earth Elements and Heavy Metals in the Surficial Sediments of the Himalayan River System. Geochemical Journal, 34, $295-319$. http://dx.doi.org/10.2343/geochemj.34.295

[10] Nozaki, Y., Lerche, D., Alibo, D.S. and Snidvongs, A. (2000) The Estuarine Geochemistry of Rare Earth Elements and Indium in the Chao Phraya River, Thailand. Geochimica et Cosmochimica Acta, 64, 3983-3994. http://dx.doi.org/10.1016/S0016-7037(00)00473-7

[11] Singh, P. and Rajamani, V. (2001) REE Geochemistry of Recent Clastic Sediments from the Kaveri Floodplains, Southern India: Implication to Source Area Weathering and Sedimentary Processes. Geochimica et Cosmochimica Acta, 65, 3093-3108. http://dx.doi.org/10.1016/S0016-7037(01)00636-6

[12] Shiller, A.M. (2002) Seasonality of Dissolved Rare Earth Elements in the Lower Mississippi River. Geochemistry, Geophysics and Geosystems, 3, 1068-1082. http://dx.doi.org/10.1029/2002GC000372

[13] Kimoto, M.A., Nearing, X.C., Zhang, D. and Powell, M. (2006) Applicability of Rare Earth Element Oxides as a Sediment Tracer for Coarse-Textured Soils. Catena, 65, 214-221. http://dx.doi.org/10.1016/j.catena.2005.10.002

[14] Jones, A.P., Wall, F. and Williams, C.T. (1996) Rare Earth Minerals Chemistry, Origin and Ore Deposits. Series: The Mineralogical Society Series, Vol. 7, Springer Publisher, Berlin.

[15] Song, Z.L., Liu, C.Q., Han, G.L., Wang, Z.L., Zhu, Z.Z. and Yang, C. (2006) Enrichment and Release of Rare Earth Elements during Weathering of Sedimentary Rocks in Wujiang Catchments, Southwest China. Journal of Rare Earths, 24, 491-496. http://dx.doi.org/10.1016/S1002-0721(06)60149-X

[16] Sultan, K. and Shazili, N.A.M. (2009) Rare Earth Elements in Tropical Surface Water, Soil and Sediments of the Terengganu River Basin, Malaysia. Journal of Rare Earths, 27, 1072-1078. http://dx.doi.org/10.1016/S1002-0721(08)60391-9 
[17] Khoo, T.T., Yaw, B.S., Kimura, T. and Kim, J.H. (1988) Geology and Paleontology of the Redang Islands, Terengganu, Peninsular Malaysia. Journal of Southeast Asian Earth Sciences, 2, 123-130. http://dx.doi.org/10.1016/0743-9547(88)90023-2

[18] Kulkarni, P., Chellam, S., Flanagan, J.B. and Jayanty, R.K.M. (2007) Microwave Digestion: ICPMS for Elemental Analysis in Ambient Airbone Fine Particulate Matter: Rare Earth Elements and Validation Using a Filter Borne Fine Particle Certified Reference Material. Analytica Chimica Acta, 599, 170-176. http://dx.doi.org/10.1016/j.aca.2007.08.014

[19] Ronov, A.B., Balashov, Y.A. and Girin, Y.P. (1974) Regularities of Rare Earth Element Distribution in the Sedimentary Shell and in the Crust of the Earth. Sedimentology, 21, 171-193. http://dx.doi.org/10.1111/j.1365-3091.1974.tb02055.x

[20] Anders, E. and Grevesse, N. (1989) Abundances of the Elements: Meteoritic and Solar. Geochimica et Cosmochimica Acta, 53, 197-214. http://dx.doi.org/10.1016/0016-7037(89)90286-X

[21] Khadijeh Saraee, R.I., Elias, S.B., Wood, A.K. and Reza, A.M. (2009) Rare Earth Elements Distribution in Marine Sediments of Malaysia Coasts. Journal of Rare Earths, 27, 1066-1077. http://dx.doi.org/10.1016/S1002-0721(08)60390-7 
Scientific Research Publishing (SCIRP) is one of the largest Open Access journal publishers. It is currently publishing more than 200 open access, online, peer-reviewed journals covering a wide range of academic disciplines. SCIRP serves the worldwide academic communities and contributes to the progress and application of science with its publication.

Other selected journals from SCIRP are listed as below. Submit your manuscript to us via either submit@scirp.org or Online Submission Portal.
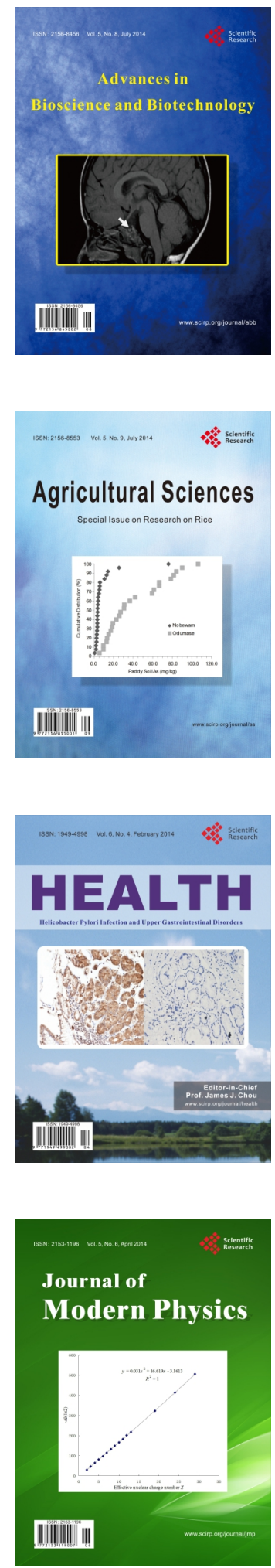
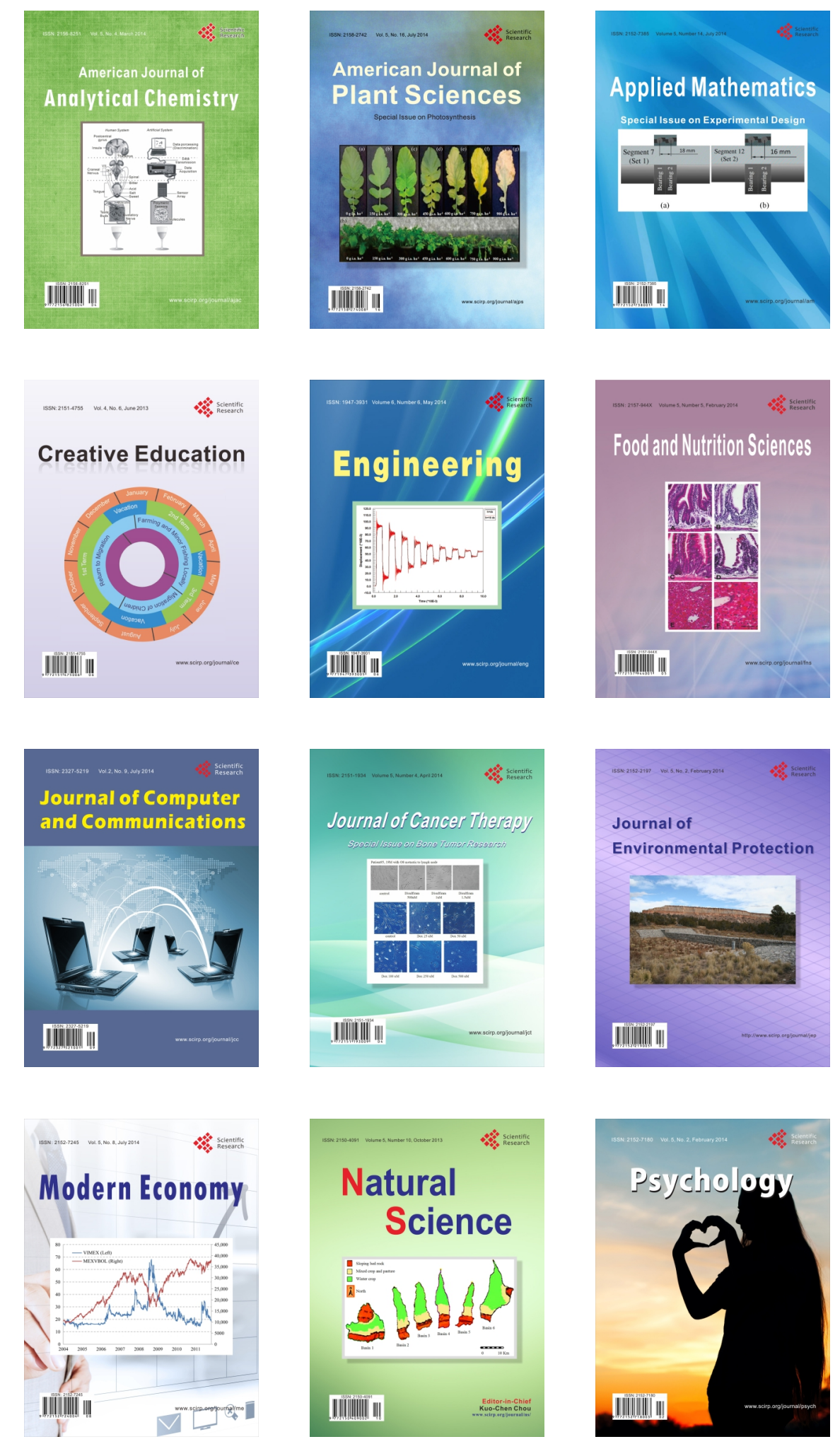